\title{
SIMBOL DALAM KUMPULAN PUISI SERIBU KEKUPU KARYA SURACHMAN RADEA MAMAN
}

\author{
Fajarisman Gunawan; Sujinah \\ MA Mambaul Ulum Bata-Bata; Universitas Muhammadiyah Surabaya \\ fajarfajarisman@gmail.com
}

ABSTRAK

ABSTRACT
Tujuan dalam penelitian ini adalah mendeskripsikan blank symbol, natural symbol, dan private symbol dalam kumpulan puisi Seribu Kekupu karya Surachman Radea Maman. Pisau bedah dalam penelitian ini menggunakan teori semiotik, yakni teori yang membahas tentang tanda dan petandanya (signifie dan signified). Metode yang digunakan adalah metode kualitatif deskriptif dengan teknik analisis secara deskriptif karena yang dihadapi dalam penelitian berupa data tentang simbol dalam kumpulan puisi Seribu Kekupu karya Surachman Radea Maman. Berdasarkan analisis data dapat disimpulkan bahwa simbol-simbol dalam kumpulan puisi Seribu Kekupu karya Surachman Radea Maman ini, hampir pada semua judul larik terdapat sajak-sajak yang menyimbolkan sesuatu yang lain. Hal tersebut terlihat pada (1) blank symbol, misalnya: mati suri, julukan manjamu, muara cinta, maha penentu, asuhan hati, kulit baja, juita, dll.; (2) natural symbol, misalnya: tinggi ujung rumput liar, dedaun tak harum atau dedaur igau, melukiskan warna langit begitu selesai hujan, dll.; (3) private symbol, misalnya: lubang kecil seperti pintu rumah merpati, hingga keujung arah buana, pada muara rahim bumi yang perawan, mengerti satuhari diri semadi, dll.

Kata Kunci: blank symbol; natural symbol; private symbol, kumpulan puisi

This research used semiotic theory approach, the theory that talks about the signs and the signified. While the method used is descriptive qualitative method with descriptive analysis techniques as the research data was in the form of the symbols in the poetry collection Seribu Kekupu by Surachman Radea Maman. The data collection techniques used the following steps: 1) codification of data, 2) identification and classification of data, 3) Interpretation of the data according to the criteria by describing meaning, and 4) Description of data qualitative findings. Based on data analysis can be concluded that the symbols in the poetry collection of Seribu Kekupu by Surachman Radea Maman, almost all titles arrays in the poems symbolize something else. It is found: (1) blank symbol, for example: torpor, nicknames Manjamu, estuaries of love, infinite determinants, heart care, steel skin, Juita, etc. (2) natural symbol, for example: high-end weeds, not fragrant foliage or dedaur igau, describe the color of the sky immediately after the rain, etc. (3) private symbol, for example: a small hole like a pigeon house door, 
until valentine direction of the globe, at the mouth of the womb of the virgin earth, understand one day of self-meditation, etc.

Keywords: blank symbol; natural symbol; private symbol, a collection of poetry

PENDAHULUAN
Karya sastra adalah hasil suatu kegiatan kreatif yang tersaji bukan hanya sebagai sebuah imitasi tetapi juga sebagai kristalisasi atau sebuah gambaran mengenai kebenaran yang dihasilkan dari berbagai bentuk dan corak tersendiri. Sastra memiliki nilai individual pengarang, bahwa yang mempunyai makna dasar dalam karya sastra itu adalah pengarang. Namun, sifat sastra yang multitafsir membuat karya sastra itu kedudukannya bebas tak terikat.

Seorang penyair dalam karya sastranya menggunakan bahasa serta mengimprovisasi bahasanya untuk menciptakan daya tarik terhadap karyanya. Dengan kehadiran bahasa, kita dapat mengucapkan kehendak, keinginan, pikiran, perasaan, ide-idenya maupun pengalaman dan kritikan. Untuk menuangkan hal tesebut ke dalam karya sastra puisi, dapat dituangkan melalui bahasa tulis dan biasanya bahasanya mengandung unsur semiotik berupa simbol-simbol yang bersifat konotatif.

Semiotik sendiri merupakan jalan keluar dari suatu ketidakpahaman makna secara strukturalisme mengenai unsurunsur bahasa dalam puisi. Dengan hadirnya ilmu tanda ini yang sekaligus sebagai pembedah sebuah makna yang tugasnya hanya bersembunyi di balik bayangan makna aslinya, tercermin sebuah gumpalan makna baru yang memang sengaja disembunyikan oleh pengguna bahasa (penyair).

Semiotik berkaitan dengan tanda. Semiotika, seperti kata Lechte adalah teori tentang tanda dan penandaan. Lebih jelasnya lagi, semiotik adalah suatu disiplin ilmu yang menyelidiki semua bentuk komunikasi yang terjadi dengan sarana signs "tanda-tanda" dan berdasarkan pada sign system (simbol) "sistem tanda" (Sobur, 2003:16).

Suatu simbol juga merupakan suatu tanda, tetapi tidak setiap tanda adalah simbol. Simbol mempunyai arti ekspresi yang mengkomunikasikan banyak arti. Simbol mengatakan sesuatu yang tidak bergantung pada diriku dan simbol mengatakan lebih dari yang dapat aku pahami. Simbol niscaya merupakan tempat istimewa pengalaman akan kelebihan arti.

Ricoeur (dalam Poespoprodjo, 2004:120) tidak memandang simbol sebagai ragam bahasa yang cacat. Bagi Ricoeur, ekspresi simbolik merupakan kepenuhan bahasa. Ambiguitas symbol bukan suatu kelemahan tetapi kekuatan, dan kekayaannya justru terletak di dalam ambiguitas tersebut.

Arti semiotik dibangun di dalam dan lewat arti harfiyah. Simbol adalah gerak arti primer yang membuat penikmat sastra mengambil bagian dalam arti yang tersembunyi sehingga mengasimilasikan pada yang disimbolisasikan tanpa dapat dikuasai 
kesamaanya secara intelektual. Jadi, intensionalitas pertama memberikan arti kedua.

Menurut Ricoeur (dalam Rafiek, 2010:12), simbol adalah ungkapan yang mengandung makna ganda. Di dalamnya terdapat makna lapis pertama yang disebut makna referensial atau denotatif. Makna lapis pertama ini mesti dirujuk pada makna lapis kedua, yaitu makna konotatif dan sugestif yang tersembunyi dibalik makna lapis pertama.

Variabel penelitiannya adalah semiotik yang terfokus pada aspek simbol yang diungkap berbeda dengan suatu lambang dengan konsep dasar yang diambil dari pendapat Aminuddin. Simbol adalah sesuatu yang tidak bergantung pada diriku dan simbol mengatakan lebih dari yang dapat aku pahami. Pada hal ini pengarang melalui puisi sebagai media yang menggunakan bahasa, mempunyai pesan-pesan yang terlampir dan tersirat dalam karyanya. Diharapkan puisi dapat memberikan kehangatan, ketentraman, juga dapat membangkitkan, menenangkan, dan menyampaikan hasrat yang ada dalam kehidupan tersirat yang ketika ditafsir maka pembaca atau penikmat sastra akan menemukan makna itu.

Berdasarkan uraian di atas, dilakukan penelitian dengan judul Simbol dalam Kumpulan Puisi Seribu Kekupu Karya Surachman Radea Maman.

METODE

Jenis penelitian ini adalah library research dengan menggunakan metode deskriptif kualitatif dengan menggunakan pendekatan semiotik. Penelitian kepustakaan atau library research dilakukan melalui bahan literatur berupa bahan-bahan yang diterbitkan baik berkenaan dengan karya sastra yang diterbitkan maupun teori-teori yang berhubugan dengan simbol dalam bahasa (Bungin, 2010:122). Dikatakan penelitian kualitatif karena penelitian ini memenuhi ciri-ciri sebagai penelitian kualitatif.

Data penelitian ini diambil dari data alamiah, yaitu kumpulan puisi Surachman Radea Maman yang berjudul Seribu Kekupu yang digunakan sebagai bahan acuan dalam proses komunikasi oleh pembacanya. Peneliti sebagai istrumen penelitian, artinya peneliti terlibat langsung atau berperanserta dalam pengumpulan data penelitian. Analisis data dilakukan secara induktif karena penelitian ini dilakukan tidak untuk membuktikan hipotesis yang telah disusun sebelumnya, melainkan merupakan pembentukan abstraksi berdasarkan bagian-bagian yang telah dikumpulkan dan dikelompok-kelompokkan. Ada batas yang ditentukan oleh fokus. Desain yang bersifat sementara, yakni desain penelitian yang digunakan senantiasa berubah dan berkembang sesuai dengan temuan objek yang diteliti.

Pernyataan di atas memperkuat pendapat Aminuddin (1990:14) bahwa penelitian kualitatif merupakan penelitian untuk menghasilkan data deskriptif berupa kata-kata atau tulisan tentang orang-orang dan perilaku yang dapat diamati. Data yang dihasilkan berupa kata-kata dan bukan berupa angka. 
Penelitian ini menggunakan pendekatan deskriptif kualitatif, yakni mendeskripsikan secara kualitatif fenomena penggunaan simbol dalam sebuah karya sastra berupa puisi. Pendekatan dalam penelitian ini, peneliti menggunakan teori semiotik dengan tujuan membedah sebuah karya sastra yang berwujud puisi. Sebagai fakta semiotik, karya sastra mempunyai eksistensi ganda, yakni berada dalam dunia indrawi (empirik) dan dunia kesadaran (non-empirik). Aspek keberadaannya yang pertama dapat ditangkap oleh indera manusia, sedangkan aspek keberadaanya yang kedua tidak dapat dialami oleh indera Faruk (2012:77-8).

Semiotik adalah ilmu tentang tanda-tanda. Ilmu ini menganggap bahwa fenomena sosial (masyarakat) dan kebudayaan itu merupakan tanda-tanda. Semiotik mempelajari sistem-sistem, aturan-aturan, dan konvensi-konvensi yang memungkinkan tandatanda tersebut mempunyai arti (Jobrahim, 2012:90).

Semiotik adalah ilmu yang membahas tentang seluk-beluk bentuk tanda. Tanda mempunyai dua aspek yaitu penanda (signifer) dan petanda (signified). Penanda adalah bentuk formalnya yang menandai sesuatu yang disebut petanda, sedangkan petanda adalah sesuatu yang ditandai oleh penanda itu sendiri.

Sumber data adalah subjek darimana data dapat diperoleh (Arikunto, 2006:129). Sumber data utama dalam penelitian kualitatif ini adalah kumpulan puisi Seribu Kekupu karya Surachman Radea Maman. Data penelitian ini menyangkut tentang sebuah sajak atau kata dalam puisi yang dapat dikatagorikan sebagai simbol (unsur tanda dalam semiotik) yang digunakan Surachman Radea Maman dalam antologi puisi Seribu Kekupu.

Metode pengumpulan data adalah rangkaian kegiatan yang dilaksanakan untuk menyelesaikan laporan penelitian. Teknik pengumpulan data dalam penelitian ini menggunakan teknik studi kepustakaan. Teknik yang digunakan menganalisis data penelitian adalah teknik analisis secara deskriptif karena data penelitian berupa simbol yang ada dalam kumpulan puisi Seribu Kekupu karya Surachman Radea Maman.

\section{PEMBAHASAN Penggunaan simbol dalam puisi Halte Tua}

Kepada lubang kecil seperti pintu rumah merpati dia berterusterang (bait pertama, baris pertama). Dilihat dari sebuah pandangan semiotik mengenai sistem tanda dan penandaannya, hal ini merupakan private symbol,yakni pada frase "lubang kecil" dan "rumah merpati". "Lubang kecil" digunakan untuk mewakili sebuah lubang pembelian tiket kereta api yang ada di setiap stasiun kereta. Selanjutnya, frase "rumah merpati" menandakan bahwa tempat pembelian tiket tersebut bentuk dan wujudnya hampir sama dengan rumah merpati.

Di bangku tunggu berlapis debu zaman (bait ketiga, baris pertama). Dilihat dari sebuah pandangan semiotik mengenai sistem tanda dan penandaannya, hal ini merupakan private symbol, yakni pada frase "berlapis debu zaman" yang digunakan untuk mewakili 
maksud bahwa kereta api tersebut kini telah berhenti beroperasi (hanya berdiam diri menunggu waktu) untuk kepastian nasibnya.

\section{Penggunaan simbol dalam puisi Potret Diri}

Berkali-kali mati suri (bait pertama, baris pertama). Dilihat dari sebuah pandangan semiotik mengenai sistem tanda dan penandaannya, hal ini merupakan blank symbol, yakni pada frase "mati suri”. Hal tersebut digunakan untuk mewakili suatu hal yang dianggap meski manusia telah beberapa kali sadar dari suatu kesalahan tetapi anehnya manusia itu tidak mudah untuk tidak mengulangi kesalahannya kembali.

Puisi berdenyut sejauh nadi (bait pertama, baris ketiga). Dilihat dari sebuah pandangan semiotik mengenai sistem tanda dan penandaannya, hal ini merupakan private symbol. Pada keseluruhan larik puisi yang digunakan untuk mewakili maksud bahwa puisi luas mencakup sesuatu, puisi mengupas bagian dalam dari arti sesungguhnya dalam suatu pesan dalam kehidupan.

Jeli menulik selagi mencincang limbah (bait kedua, baris kedua). Dilihat dari sebuah pandangan semiotik mengenai sistem tanda dan penandaannya, hal ini merupakan private symbol, yakni pada frase "mencincang limbah" yang digunakan untuk mewakili maksud yang sebenarnya. Artinya, kehidupan manusia semestinya dengan benar memilah dan memilih mana perbuatan baik dan mana perbuatan yang tidak baik.

\section{Penggunaan simbol dalam puisi Hubungan kita}

Betapa aku pernah melukiskan warna langit begitu selesai hujan (bait kedua, baris kedua). Dilihat dari sebuah pandangan semiotik mengenai sistem tanda dan penandaannya, hal ini merupakan natural symbol. Frasa "warna langit begitu selesai hujan" digunakan untuk mewakili maksud yang sebenarnya, yaitu menggambarkan suatu keindahan pada masa yang pernah dilalui oleh sepasang kekasih dengan sangat indah, sejuk, dan seakan-akan seperti indahnya pelangi.

Menangkap redup suaraku (bait keempat, baris keempat). Dilihat dari sebuah pandangan semiotik mengenai sistem tanda dan penandaannya, hal ini merupakan private symbol. Frase "redup suaraku" digunakan untuk mewakil perasaan sedih yang dialami oleh penyair. Sebenarnya, hal ini suatu perkataan hiburan yang diciptakan penyair untuk penyair sendiri yang telah bersedih karena seseorang yang sangat berharga untuk hidupnya tidak dimilikinya.

\section{Penggunaan simbol dalam puisi "Musik alam"}

Musik alam sebenarnya beraturan (Bait pertama, baris pertama). Dilihat dari sebuah pandangan semiotik mengenai sistem tanda dan penandaannya, hal ini merupakan natural symbol. Frase "Musik alam" digunakan untuk mewakili maksud bahwa sebenarnya jalannya hidup ini sudah di atur dan telah ada yang mengatur. Kita hanya menjalankan sebaik mana kita berusaha untuk jalan yang terbaik. 
Menyimpang dari melodi (bait pertama, baris keempat). Dilihat dari sebuah pandangan semiotik mengenai sistem tanda dan penandaannya, hal ini merupakan private symbol. Kata "melodi" digunakan untuk mewakili maksud dari suatu kehidupan yang baik atau kehidupan yang indah. Jadi, maknanya keseluruhan, menyimpang dari kebaikan/keindahan yang diinginkan sebelumnya.

\section{Penggunaan simbol dalam puisi "Sujud Sang Waktu"}

Arus sejarah sarwa fana (bait kedua, baris kedua). Dilihat dari sebuah pandangan semiotik mengenai sistem tanda dan penandaannya, hal ini merupakan private symbol. Semua larik digunakan untuk mewakili maksud bahwa jika kita mengenal waktu dan tahu terhadap waktu yang akan terus berjalan, seharusnya perbuatan kita dan tingkah laku kita digunakan dengan baik sebelum kematian menjemput. Yang kekal hanyalah waktu dan waktu tidak dapat diputar kembali sesuai dengan penyesalan-penyesalan yang diluapkan oleh manusia.

Dari dahulu sujud hanya ke Maha Penentu (bait keempat, baris kedua). Dilihat dari sebuah pandangan semiotik mengenai sistem tanda dan penandaannya, hal ini merupakan blank symbol. Frase "maha Penentu" yang digunakan untuk mewakili makna yang sebenarnya adalah Allah Swt.

\section{Penggunaan simbol dalam puisi Menuju-Mu}

Berdesir kuncup-kuncup kahidupan (bait pertama, baris kedua). Dilihat dari sebuah pandangan semiotik mengenai sistem tanda dan penandaannya, hal ini merupakan natural symbol. Frase "kucupkuncup” yang digunakan untuk mewakili maksud bahwa telah masuk pada akhir-akhir kehidupan. Artinya, setelah kita hidup sekian lama, akan segera berakhirlah kehidupan itu pada waktunya.

Pada muara rahim bumi yang perawan (bait kedua, baris keempat). Dilihat dari sebuah pandangan semiotik mengenai sistem tanda dan penandaannya, hal ini merupakan private symbol. Frase "muara rahim bumi yang perawan" yang digunakan untuk mewakili maksud dimana semuanya hanya sekali dikubur (pada akhirnya manusia dikuburkan).

\section{Penggunaan simbol dalam puisi Gunung-Gunung}

Ditumbuhi belantara pekat dan lumut waktu (bait pertama, baris pertama). Dilihat dari sebuah pandangan semiotik mengenai sistem tanda dan penandaannya, hal ini merupakan natural symbol. Keseluruhan larik puisi digunakan untuk mewakili sebuah penjelasan bahwa penyair ingin menjelaskan tentang sesuatu yang menjadi ingatan sepanjang masa meski hal itu dimakan waktu. Simbol tersebut digunakan untuk menggambarkan sebuah sesuatu yang telah lama ada dan takkan terlupakan hingga akhir zaman.

Gunung Para Rasul (bait kedua, baris kedua). Dilihat dari sebuah pandangan semiotik mengenai sistem tanda dan penandaannya, hal ini merupakan natural symbol. Kata “Gunung” digunakan untuk 
mewakili sebuah pendirian dan perjuangan yang kuat dari para Rasulullah dan diyakini oleh masyarakat Islam.

Tertidur ditimang abad (bait keempat, baris ketiga). Dilihat dari sebuah pandangan semiotik mengenai sistem tanda dan penandaannya, hal ini merupakan private symbol. Keseluruan larik puisi digunakan untuk mewakili sebuah penjelasan bahwa gunung adalah para Nabi/Para Rasul yang dikenang dan diyakini keberadaannya meski telah mati raganya namun tetap hidup jiwa dan tanggung jawabnya.

\section{Penggunaan simbol dalam puisi Seribu Kekupu}

Yang dilahap dari sumbernya oleh seribu kekupu (bait pertama, baris kedua). Dilihat dari sebuah pandangan semiotik mengenai sistem tanda dan penandaannya, hal ini merupakan natural symbol, yakni pada kata "sumbernya" dan "seribu kekupu". Kata "sumbernya" mewakili maksud sebuah wadah atau tempat mata pencaharian, sedangkan "seribu kekupu” adalah manusia sebagai pencari tempat itu. Berdasarkan hal tersebut, dapat diketahui bahwa makna dari puisi tersebut adalah sebuah mata pencaharian yang dicari oleh seluruh manusia untuk kemakmuran hidupnya.

Menggelar batik-batik sayapnya sebelum melesat dari landasan fana terhina (bait kedua, baris ketiga). Dilihat dari sebuah pandangan semiotik mengenai sistem tanda dan penandaannya, hal ini merupakan private symbol. Keseluruhan larik puisi digunakan untuk mewakili berbagai macam keragaman perbuatan yang dilakukan dalam kehidupan, sebelum kematian menjemput (duniaakhirat).

Mengerti satu hari diri Semadi (bait ketiga, baris ketiga). Dilihat dari sebuah pandangan semiotik mengenai sistem tanda dan penandaannya, hal ini merupakan private symbol. Kata "semadi" digunakan untuk menggambarkan sebuah kematian dimana pada saat itu di dalam kubur tersebut hanyalah sendiri yang seakan seperti orang bertapa yang akan jauh dari orang-orang ditempat suram dan sangat gelap.

\section{Penggunaan simbol dalam puisi Ibu dan Anak}

Digembalanya asuhan hati yang baru bisa berlari (bait pertama, baris kedua). Dilihat dari sebuah pandangan semiotik mengenai sistem tanda dan penandaannya, hal ini merupakan blank symbol. Frase "asuhan hati” digunakan untuk mewakili makna satu kehidupan yang baru lahir yang dibesarkan dengan kasih sayang oleh induknya.

Serba putih bergaris hitam (bait kedua, baris kedua). Dilihat dari sebuah pandangan semiotik mengenai sistem tanda dan penandaannya, hal ini merupakan private symbol. Frase "putih bergaris hitam" digunakan untuk mewakili hewan berkaki empat yang bernama zebra.

Penggunaan simbol dalam puisi Sekali Berahi. Sudah itu...

Di lidah buih semua garam birahi mendidih (bait pertama, baris pertama). Dilihat dari sebuah pandangan semiotik mengenai 
sistem tanda dan penandaannya, hal ini merupakan private symbol. Seluruh larik puisi digunakan untuk mewakili penjelasan bahwa pada saat itu penyair sedang nafsu-nafsunya melihat lauk makanan laut yang sangat lezat (ikan salmon) itu.

Santan kejantanan membuncah (bait pertama, baris kedua). Dilihat dari sebuah pandangan semiotik mengenai sistem tanda dan penandaannya, hal ini merupakan private symbol. Seluruh larik puisi yang digunakan untuk mewakili penjelasan tentang rasa lapar yang luar biasa dengan nafsu yang teramat sangat.

Sebab jauh dibalik muara cinta (bait kedua, baris ketiga). Dilihat dari sebuah pandangan semiotik mengenai sistem tanda dan penandaannya, hal ini merupakanblank symbol. Frase "muara cinta" digunakan untuk mewakili makna yang sebenarnya. Makna dalam puisi adalah kesukaan atau suatu keinginan besar untuk menikmatinya (makanan). Oleh sebab itu, ikan salmon memilih tengah laut untuk hidupnya.

\section{Penggunaan simbol dalam puisi Di Tepi Rawa Sebuah Hutan}

Tidak selamanya tetes hujan kembali di laut (bait pertama, baris pertama). Dilihat dari sebuah pandangan semiotik mengenai sistem tanda dan penandaannya, hal ini merupakan natural symbol. Frase "tetes hujan" dan kata "laut” digunakan untuk menjelaskan bahwa tidak selamanya kehidupan manusia akan mudah untuk dijalani. Tidak mudah manusia kembali suci setelah kesalahan dengan mudahnya dilakukan.

Mungkin ia terperangkap sihir daun (bait pertama, baris kedua). Dilihat dari sebuah pandangan semiotik mengenai sistem tanda dan penandaannya, hal ini merupakan natural symbol. Frase "sihir daun" digunakan untuk mejelaskan kemungkinan manusia terjebak atau terlarut dengan urusan duniawi yang berbau kekayaan, harta, dan wanita.

Boleh saja ia berhasil menerobos kulit ari tanah tapi dihisap akar-akar pohon (bait pertama, baris ketiga). Dilihat dari sebuah pandangan semiotik mengenai sistem tanda dan penandaannya, hal ini merupakan natural symbol. Frase "kulit ari tanah" dan "akar-akar pohon" digunakan untuk mejelaskan maksud bahwa bisa saja manusia lolos dari satu perbuatan tidak baik, tetapi tidak akan lolos dari api neraka.

\section{Penggunaan simbol dalam puisi Senja Akhir di Arena}

Ada yang terpatung ditenung seratus jurus (bait pertama, baris ketiga). Dilihat dari sebuah pandangan semiotik mengenai sistem tanda dan penandaannya, hal ini merupakan private symbol. Frase "terpatung seratus jurus" digunakan untuk menjelaskan maksud bahwa ada yang terdiam dengan setengah sadar diakibatkan pukulan-pukulan.

Sobek kulit baja, tembus ke jantung (bait kedua, baris ketiga). Dilihat dari sebuah pandangan semiotik mengenai sistem tanda dan penandaannya, hal ini merupakan blank symbol. Frase "kulit baja" 
digunakan untuk mewakili sebutan bagi orang yang kuat sehingga dianggapnya kulitnya sekeras baja.

Ternyata Cuma bayangan akhir senja (bait ketiga, baris pertama). Dilihat dari sebuah pandangan semiotik mengenai sistem tanda dan penandaannya, hal ini merupakan natural symbol. Frase "bayangan akhir senja” digunakan untuk mewakili maksud bahwa penyair ingin menjelaskan sesuatu yang mendekat terhadap pintu kematian.

\section{Penggunaan simbol dalam puisi Crocodilarium}

Menyamar bagai kayu lapuk yang mengambang (bait pertama, baris kedua). Dilihat dari sebuah pandangan semiotik mengenai sistem tanda dan penandaannya, hal ini merupakan natural symbol. Frase "kayu lapuk yang mengambang" digunakan untuk mewakili maksud pengarang yang ingin mendeskripsikan tetang tingkah laku hewan buas seperti buaya yang biasa menyamar untuk memangsa.

Ngeri yang purba meriapkan bulu romaku (bait kedua, baris ketiga). Dilihat dari sebuah pandangan semiotik mengenai sistem tanda dan penandaannya, hal ini merupakan private symbol. Kata "purba” yang digunakan untuk mewakili hewan buas yang bernama buaya. Buaya sangat berbahaya dan menakutkan bagi siapa saja yang mendekat.

\section{Penggunaan simbol dalam puisi Nuansa Malam}

Duduklah di sini, juita (bait pertama, baris pertama). Dilihat dari sebuah pandangan semiotik mengenai sistem tanda dan penandaannya, hal ini merupakanblank symbol. Kata "juita" digunakan untuk mewakili kata panggilan yang dikhususkan kepada orang yang dicintai.

Kitab biografi itu menutup garis pahamu (bait kedua, baris kedua). Dilihat dari sebuah pandangan semiotik mengenai sistem tanda dan penandaannya, hal ini merupakan private symbol, yakni pada frase "Kitab biografi" dan "garis pahamu". Frase "Kitab biografi" maksudnya memori atau kenangan yang selama ini disimpannya. Frase "garis pahamu" digunakan untuk mewakili maksud bahwa janji cinta yang menentukan dan membatasi pergaulanmu (orang terkasih dari seorang penyair).

\section{Penggunaan simbol dalam puisi Pertemuan}

Mimpi yang berulang kali (bait pertama, baris ketiga). Dilihat dari sebuah pandangan semiotik mengenai sistem tanda dan penandaannya, hal ini merupakan blank symbol. Kata "Mimpi" digunakan untuk mewakili sebuah keinginan dari seorang penyair tentang sesuatu yang ingin dicapainya.

Sehabis hangat bercumbu (bait kedua, baris ketiga). Dilihat dari sebuah pandangan semiotik mengenai sistem tanda dan penandaannya, hal ini merupakan blank symbol. Frase "hangat bercumbu" digunakan untuk mewakili maksud penyair yang ingin mengungkapkan suatu pertemuan yang pernah terjadi berdua 
tentang suatu kebersamaan dengan didasari oleh rasa cinta oleh keduanya.

SIMPULAN

Berdasarkan hasil penelitian dan pembahasan yang telah dilakukan dengan menggunakan teori semiotik tentang simbol dalam antologi puisi Seribu Kekupu Karya Surachman Radea Maman ini, dapat ditarik kesimpulan bahwa di dalam kumpulan puisi tersebut terdapat simbol yang ada dalam setiap sajak-sajak puisi yang dianalisis, diantaranya adalah blank symbol, natural symbol, dan private symbol.

(1) Blank symbol adalah meskipun maknanya bersifat konotatif, tetapi pembaca tidak perlu menafsirkannya karena acuan maknanya sudah bersifat umum. Dalam kumpulan puisi Seribu Kekupu karya Surachman Radea Maman, penggunaan blank symbol yang mewakili berbagai persoalan dalam kehidupan diantaranya adalah asuhan hati, muara cinta, kulit baja, otot beton, juita, dan senyum merah jambu.

(2) Natural symbol adalah simbol yang penggunaan bahasanya menggunakan realitas alam. Dalam kumpulan puisi Seribu Kekupu karya Surachman Radea Maman, penggunaan natural symbol yang sebagian mendeskripsikan sebuah hidup yang pada akhirnya akan tua dan mati diantaranya adalah Dia merenung dan menaksir tinggi ujung rumput liar, perlahan berdesirkuncup -kuncup kehidupan, dan ternyata cuma bayangan akhir senja.

(3) Private symbol adalah simbol yang penggunaan bahasanya itu secara khusus diciptakan dan digunakan penyairnya. Dalam kumpulan puisi Seribu Kekupu karya Surachman Radea Maman, misalnya penggunaan private symbol yang mendeskripsikan sebuah kehidupan dari awal kita hidup hingga kita tua dan mati diantaranya adalah kepada lubang kecil seperti pintu rumah merpati dia berterus terang, di bangku tunggu berlapis debu zaman, pada muara rahim bumi yang perawan, dan mengerti satu hari diri semadi.

\section{DAFTAR PUSTAKA}

Aminuddin. 2011. Pengantar Apresiasi Karya Sastra. Malang: Sinar Baru Algensindo.

Arikunto, $\quad$ Suharsimi. 2006. ProsedurPenelitian Suatu pendekatan Praktik. Jakarta: Rineka Cipta.

Faruk. 2012. Metode Peneltian Sastra. Jakarta: Pustaka Pelajar.

Jobrahim. 2012. Teori Penelitian Sastra. Yogyakarta: Pustaka Pelajar.
Poespoprojdo. 2004. Hermeneutika. Bandung: Pustaka Setia.

Rafiek, M. 2010. Teori Sastra Kajian Teori dan Praktik. Bandung: PT. Rafika Aditama.

Sobur, Alex. 2003. Semiotika Komunikasi. Bandung: PT. Remaja Rosda karya. 